\title{
Ірина Малик
}

Національний університет «Львівська політехніка»

\section{Міністерства Правди: формування та підтримка базових наративів інформаційними міністерствами так званих «ЛДНР»}

Особливістю сучасного історичного періоду, в якому перебуває Україна є необхідність швидкого реагування на абсолютно донедавна незнайомі нові виклики та загрози. Як довів досвід останніх років, найважливішою складовою національної безпеки держави $є$ інформаційна безпека. Нехтування загроз у цій сфері призводить до економічних катастроф, дипломатичних криз, військових конфліктів, війн, територіальних втрат. Інформаційні війни - це війни майбутнього, які мають безліч переваг над збройним вирішенням конфліктів: це і відносно менша економічна витратність, і анонімний характер ворога (що ускладнює контрдіi), і відсутність інформаційних кордонів у сучасному глобалізованому світі, і неможливість встановити правила гри. Найпоширенішими методами реалізації поставленої мети в інформаційній війні є пропаганда, маніпуляція, дезінформація, диверсифікація суспільної свідомості. Поряд з цим однією з основних складових інформаційного протиборства є наратив, який покликаний комплексно формувати суспільну свідомість.

Дане дослідження є продовженням вивчення інформаційного поля окупованих територій Донбасу, розпочатого у статті «Деякі аспекти гуманітарних викликів безпечних реінтеграційних процесів ТОТ ОРДЛО: роль 3МІ».

Метою дослідження є виокремлення та формулювання основних месиджів та наративів, що є базовими для сучасної інформаційної політики квазідержав ТОТ ОРДЛО. Задля реалізації поставленої мети необхідно виконати такі завдання:

- виокремити сучасні теоретичні підходи для поняття «наратив»:

- проаналізувати сайт «Міністерства інформації Донецької народної республіки» та «Міністерства зв’язку та масових комунікацій Луганської народної республіки»:

- на основі аналізу контенту сайтів міністерств виокремити, та сформулювати основні наративи та месиджі, які є базовими для інформаційної політики на окупованих територіях.

Гіпотеза: сучасна інформаційна політика, яку формулює квазівлада, не сприяє безпечній реінтеграції окупованих територій та формує у суспільній свідомості наративи, що працюють на зближення з РФ.

3'ясовано основні новинні тематики та проекти, які реалізовують міністерства так званих «ЛДНР».. Детально досліджено тематику новин (проаналізований період - січень 2021 р.), котрі були згруповані у шість основних блоків. Встановлено відсоткову вагу кожного новинного блоку, що і було візуалізовано в роботі за допомогою графічного методу.

На основі проведеного аналізу новинної стрічки міністерств так званих «ЛДНР», що відповідають за інформаційну політику, були виокремлені основні наративи, які працюють на формування суспільної свідомості в ТОТ ОРДЛО.

Ключові слова: наратив, інформаційна політика, ЛДНР, гібридна війна, контент, пропаганда

Iryna Malyk

Lviv Polytechnic National University

\section{Ministry of Truth: Formation and support of the main rhetoric by informational ministries of so-called Luhansk and Donetsk People's republics}

The peculiarity of the contemporary historical period, Ukraine is currently in, is the necessity of rapid reaction to new challenges and threats, which were absolutely unknown recently. The experience of recent years showed that information security is the most important component of the national security of the state. Neglect of threats in this area leads to economic catastrophes, diplomatic crises, military conflicts, wars and territorial losses. Information warfare is the war of the future, having numerous advantages over armed conflict resolution: these include relatively lower economic costs, anonymous nature of the enemy (which complicates contractions), and absence of informational borders in modern globalized world, as well as inability to set the rules of the game. The most spread methods of realization of the set goals in the information warfare are propaganda, manipulation, disinformation, and diversification 
of public consciousness. Herewith, one of the main components of the information warfare is rhetoric, aimed to form public consciousness in a holistic way.

This research is the continuation of the study of the informational field of the occupied territories of Donbas, started in the article "Some aspects of humanitarian challenges of safe reintegration processes of Temporary Occupied Territories of Separate Districts of Donetsk and Luhansk Regions: role of mass media".

The research aims to distinguish and formulate the main messages and rhetoric, which are basic for the contemporary informational policy of quasi-states on the Temporary Occupied Territories of Separate Districts of Donetsk and Luhansk Regions. For the realization of the set aim, the following tasks should be performed:

- distinguishing of theoretical approaches to the concept "rhetoric":

- analysis of the website of the "Ministry of Information of Donetsk People's Republic" and "Ministry of communication and mass communication of Luhansk People's Republic":

- distinguishing and formulation of the main rhetoric and messages, which are basic for the informational policy on the occupied territories, based on the analysis of the content of the websites of ministries.

Hypothesis: Contemporary informational policy, which is formulated by the quasi-government, does not facilitate safe reintegration of the occupied territories into Ukraine and forms rhetoric, working for approaching with the Russian Federation, in the public consciousness.

The main news themes and projects, the ministries realized, were determined. Themes of news (the period analysed - January 2021), which were further grouped into six main blocks were studied. The percentage weight of each news block was determined and further visualized in the work using the graphic method.

The main rhetoric, working at the formation of public consciousness in "republics" was defined on the basis of the conducted analysis of the news feed of the ministries responsible for information policy in Luhansk and Donetsk People's republics.

Keywords: rhetoric, information policy, Luhansk and Donetsk People's republics, hybrid war, content, propaganda

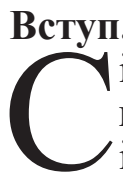

Вступ.

ім років - це доволі незначний відрізок часу, коли йдеться про існування та розвиток держави, проте великий термін, коли йдеться про життєвий шлях людини. Ось уже майже сім років як Україна, внаслідок російської агресії, втратила частину своєї території - автономну Республіку Крим та частину Луганської та Донецької областей (ТОТ ОРДЛО). Війна загострила ті проблеми та виклики, які здавались незначними і зробила нездоланним ті, які були на поверхні. Після початку російсько-української війни розвиток окупованих територій не зупинився, проте відбувався не паралельно 3 розвитком української держави. Відправною точкою початку розвитку у різних напрямках, орієнтуючись на різні вектори, став 2014 рік. Гібридна війна, котра має різні складові, а, отже, і різні методи реалізації поставленої мети, за основу бере інформаційну сферу. Саме контрольована та у відповідному напрямку спрямована інформаційна політика може стати підгрунтям для успішних військових операцій, економічних війн, створення екологічних катастроф та дипломатичних баталій.

Тож, об'єктом даного дослідження є діяльність «Міністерства зв’язку та масових комунікації Луганської народної республіки» та «Міністерства інформації Донецької народної республіки». Предметом дослідження у даному випадку є проекти та новинна стрічка міністерств, аналіз сайтів 3 огляду на питання та проблематику, що піднімається. Метою дослідження є: на основі аналізу контенту сайтів міністерств виокремити, та сформулювати основні наративи та меседжі, які покликані стати основою інформаційної політики так званих «ЛДНР».

\section{Результати дослідження.}

Як формулює український дослідник стратегічних комунікацій Ожеван М.A., стратегічними наративами (лат. narrare оповідати) у політичному сенсі $\epsilon$ засоби, до яких вдаються політичні актори, щоб сконструювати смисли та значення «великої політики» - як внутрішньої, так і зовнішньої, якдержавної,такікорпоративної,громадської тощо. Цінність подібних наративів полягає у їх спроможності до більш-менш безконфліктного розповсюдження (Ожеван, 2014, с. 30). Тож, саме за допомогою стратегічних наративів можливо на рівні держави, корпорації чи організації окреслити свої інтереси, напрямки та моделі розвитку.

У «Словнику сучасної політичної лексики» термін «наратив» (з лат. як мовний 
акт) - це історично і культурно обгрунтована інтерпретація деякого аспекту світу з певної позиції... Класичною сферою виникнення та функціонування наративу виступає історія... Наратив визначає інтерпретацію історичних фактів у єдиному варіанті, а також показує неприпустимість інших пояснень (Сучасна політична лексика (за А. Гарбадин), 2015, c. 182).: Тож, за таким визначенням, наратив - це невід'ємна (навіть базова) складова інформаційної політики, елемент пропаганди, маніпуляції та інформаційнопсихологічного впливу.

Колектив авторів монографіï, що ініційована Інститутом міжнародних відносин Київського Національного Університету імені Т. Шевченка дослідив розробки фахівців-міжнародників, що пропонують розуміння наративу на трьох взаємопов'язаних рівнях: - міжнародна система наративу, яка описує якою $\epsilon$ структура світу, іiі елементи і як вона працює; - національні розповіді, які презентують історію держави, іiі цінності та цілі; - наратив проблеми, в якому викладено, чому потрібна саме така політика і як вона буде успішно впроваджуватися. (Стратегічні комунікації в міжнародних відносинах, 2019, с. 47).

На думку Г. Почепцова, сучасний світ створено 3 наративів, які містяться у кіно, книгах, газетах, розмовах. Наративи дозволяють відмежовувати погані вчинки від хороших, розглядати, аналізувати ту чи іншу ситуацію, надаючи оцінку подіям. (Почепцов, $2012 b$, с. 236). Саме завдяки наративам та контенту, який на це працював (преса, художні, документальні та мультиплікаційні фільми), в часи СРСР радянська людина знала про існування проблем «загниваючого заходу», про загрозу атомної війни з боку США (про яку розповідали в школах дітям на так званій політінформації), про відважних радянських воїнів, що перемогли німецький фашизм (звісно ж без будь-якої сторонньої допомоги!), про зажерливих ворогівзапроданців, котрі цілодобово працювали на розпад Радянського Союзу. Створення образу ворога, в даному випадку, об'єднує та пояснює причини негараздів та невдач.. Цей «ворог» в радянській політичній міфології змінювався в залежності від доцільності, історичних потреб, зовнішніх викликів та загроз. В середині країни спершу це були «куркулі», яких треба було «розкуркулювати», щоб відібрати продукти та поділити рівномірно між усіма громадянами так званих «ЛДНР», пізніше «буржуазні націоналісти», які розхитували підвалини державності, ще пізніше - «гнилий прошарок - інтелігенція» (ймовірно, термін авторства В. Леніна), який вигадує невідомо що, хоче невідомо що, замість того, щоб іти на роботу і будувати світле майбуття.

Тож, і у сучасному світі за допомогою наративів людина простіше орієнтується по вектору свій-чужий, друг-ворог. 3 початку російсько-української війни Україна робить спробу сформулювати свої власні наративи. Адже до 2014 року (а подекуди і зараз) Україні насаджувалися міфи інших держав. Внаслідок чого міфологічний простір України займає міфологія, зокрема, Росії. (Карпиленко В., 2015, с. 551; Почепцов, 2012a). Найпоширенішими 3 них були: існування доброго старшого брата, єдина велика слов'янська родина зі спільними цінностями та баченням майбутнього, недолуга Україна-окраїна, неспроможна побудувати ні демократичні інститути влади, ні самостійну державу, де пересічний українець подавався як хитруватий, не дуже розумний, без моральних цінностей, проте такий, що на все готовий заради власної вигоди (серіали «Моя прекрасна няня», «Слід»). Проте за сім років війни, завдяки подіям останніх років, критичному осмисленню інформації, блокуванню пропагандистського контенту (забороні соціальної мережі «ВКонтакте», російської електронної пошти Mail.ru, низки фільмів, що пропагували велич російської армії на героїзували органи внутрішніх справ), кут сприйняття та прийняття наративів сусідньої держави населенням України дещо змінився. Але! Натомість власні наративи не з'явились. Хто ворог для України століттями? Чому? Як це трапилось? I найголовніше: як до цього ставитись? (Карпиленко, 2014, с. 10).

Як зазначає у своїй праці «Глобальна війна стратегічних наративів: виклики та ризики для України» д.ф.н., проф. М. Ожеван (Ожеван, 2014, с. 34), одну з найбільш переконливих моделей наративу (delineating story patterns) запропонував в 1972 році соціолінгвіст Уїльям Лейбов. Згідно 3 цією класифікацією, наратор, вибудовуючи 
наратив, намагається відповісти на такі запитання.

1. Анотація (Abstract). Як це все сталося і 3 чого усе почалося?

2. Орієнтація (Orientation). Хто/що були у це задіяні, коли й де?

3. Кульмінація (Complicating Action). Що ж трапилося?

4. Розв'язка (Resolution). Чим же це, зрештою, закінчилося?

5. Оцінка (Evaluation). Як до цього ставитися?

6. Фінал (Coda). Що це все означає?

На думку українського дослідника соціальних комунікацій Г.Почепцова, виборець знаходить той наратив, який більше його задовольняє, чия модель світу для нього ближча. (Почепцов, 2012a). Тож «близькість» тієї чи іншої моделі формують за допомогою відповідного контенту, який працює в рамках певного наративу.
Особливої уваги заслуговує сайт «Міністерства інформації ДНР», наповнення якого повністю відповідає своїй назві. Окрім основної діяльності - акредитації журналістів, рекламного регулювання, ліцензування телерадіомовлення, реєстрації ЗМI, законодавчої діяльності (як от «Закон про ЗМІ», «Закон проліцензування», «Закон про рекламу») - міністерство займається додатковими проектами, які можна класифікувати як інформаційно-пропагандистська діяльність. До таких проектів, представлених на сайті, відносять «ДНР онлайн», «Все про ДНР», «Білі журавлі», «Трибунал» (доступ до цього проекту в мережі онлайн утруднений - не зовсім зрозуміло, чи блокується зі сторони України, чи стороною «ДНР»).

Проект «Білі журавлі» присвячений «пам'яті воїнів, що стали на захист Батьківщини в священній війні проти українського фашизму» («Білі журавлі»).

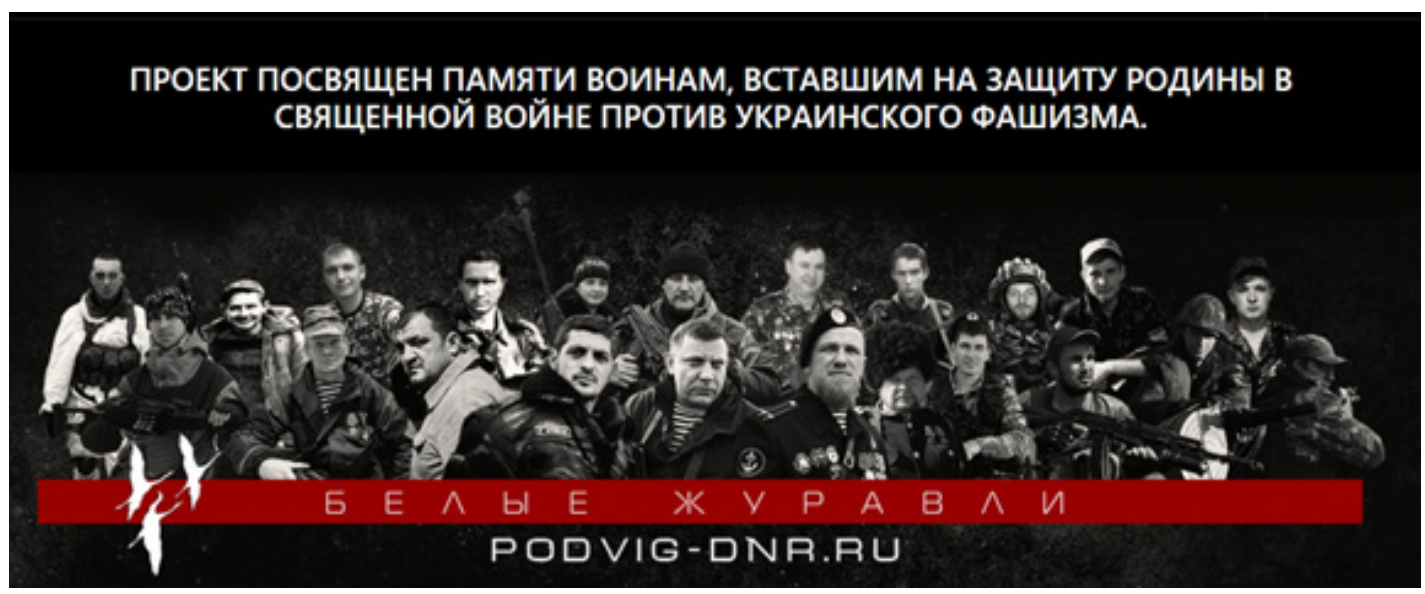

На передньому плані - загиблі «герої» так званої «ДНР». Все наповнення сайту пронизане паралелями: український фашизм - німецький фашизм. Звісно, що прямо про це не говориться, проте новини про здобутки, перемоги Радянської армії у
Другій світовій війні та звірства німецької армії подаються поряд 3 новинами про звірства «військових формувань України» (ВФУ - термін, яким оперують у «ДНР»). Візуально це поєднується таким чином: 


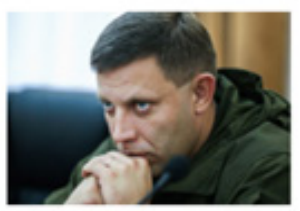

Захарченко Алексамар Владимирович еБатя:

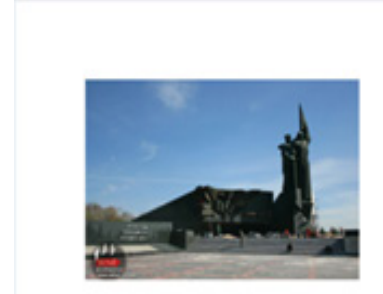

Eлизавета Буторская (r.

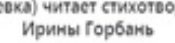

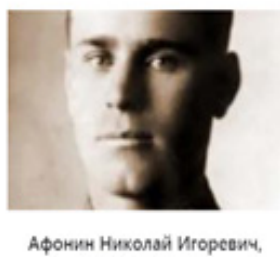
участиик ВOB

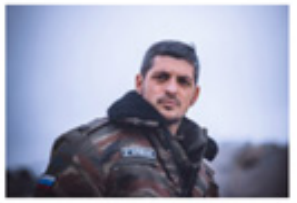

Толетьох Михами Ceprecenu afuents

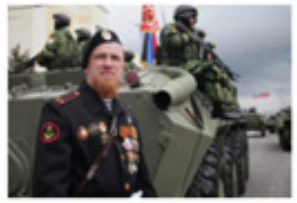

Паелое Арсен Сергесеич amotopona.

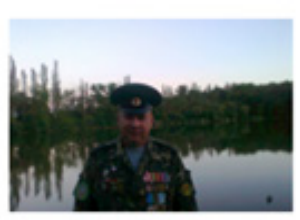

Гришин Олег Гриторьесич Meavcab:

\section{БЕССМЕРТНЫЙ ПОЛК ДОНБАСС}

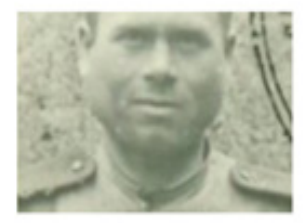

Мсщератхо Фсаор Иоанович -

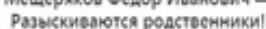

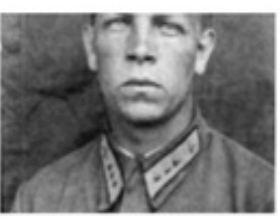

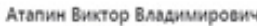
участиик ВOB

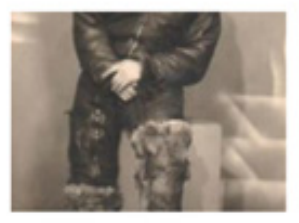

Боламрев Влааимир Иеаноеич, участник ВОВ

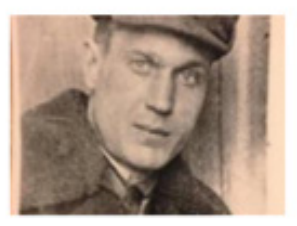

AmTunoe Arexcarap Cepreceny, участмик ВОВ

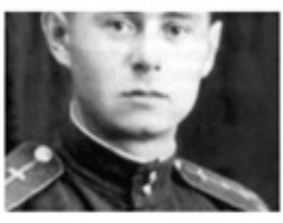

Без6окое Вмамимир Михаймович, участник ВОВ

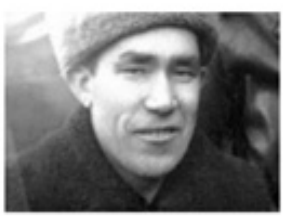

Arapece Anekearap Алексамарович, участких вOB
Найбільше серед «Проектів Міністерства» вражає «Трибунал - Сайт про злочини ЗСУ в Донецькій народній республіці» (Трибунал) У випадку, коли сторінка відкривалась, можна було побачити ретельно проведене дослідження щодо воїнів ЗСУ, котрі були учасниками військових дій на території області та потрапили в полон. Їх усіх було «посортовано» за місцем народження по областях України (були і 3 інших країн). На кожного заведена «Справа», де містилась персональна фотографія та коротка біографічна довідка 3 вказаним військовим званням, номером частини, де служив. Зараз ця сторінка не доступна. Натомість віднедавна «Міністерство» має свій You-tube канал з 34,7 тис. дописувачів. Канал має декілька рубрик - «Народна Рада ДНР», «Голова Донецької Народної Республіки», «Популярне» (з відео, які набрали найбільше переглядів). Окремої уваги $з$ огляду на тематику дослідження заслуговують рубрики «УНМ ДНР»
(Управління народної міліції) та «Наслідки обстрілів ВФУ». Тут 3 детальними описами та відео подається інформація щодо порушень міжнародних угод «ВФУ», які ведуть безперервний обстріл території республіки. Для більш вражаючого ефекту подається репортаж від 07.05.2020 p. 3 Новоазовської центральної районної лікарні, куди потрапили поранені діти внаслідок обстрілу ЗСУ. Найбільше ж переглядів на каналі набрали відео «Пам'яті Михаіла Толстих» («Гіві») 1,2 млн переглядів та уривок 3 концерту російського співака Олександра Маршала під назвою «На безіменній висоті», який відбувся в Донецьку 11 травня 2017 р. Репертуар складався 3 російськомовних патріотичних пісень часів «Великої вітчизняної війни» - 861 тис. переглядів.

Задля кращого розуміння злостної політики формування новин, що працюють на підтримку сформованих наративів та формування нових, був проведений аналіз новинної стрічки. 


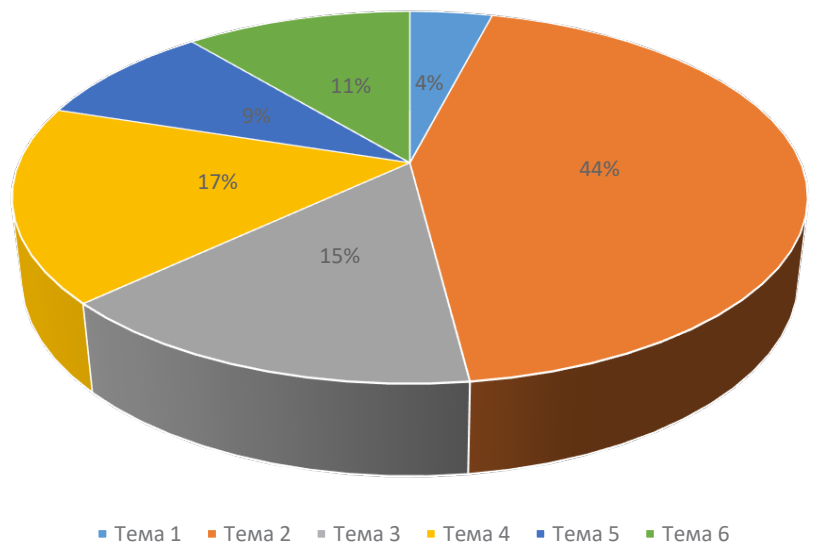

Діаграма 1. Новинна тематика сайту Міністерства інформацї ДНР за січень 2021 р.

Тематика січневих новин 2021 р. «Міністерство інформації ДНР» була згрупована у шість основних блоків (діаграма 1), прораховано кількість новин в кожному блоці, встановлено пріоритетність та насиченість кожного блоку. Тож, у січні говорили про:

$44 \%$ - Порушення режиму вогню противником. Сюди були віднесені новини на кшталт «При обстрілі території республіки ВФУ застосовували міномети, гранатомети, стрілецьку зброю Представництво ДНР в СЦКК» (Спільний центр контролю та координації), «Противник шість разів порушив режим припинення вогню - Представництво ДНР в СЦКК», «ВФУ вели вогонь по Ясиноватій - Представництво ДНР в СЦКК».

$17 \%$ - умовний блок новин під назвою «Діди воювали». Сюди потрапили такі новини: «900 днів блокади», «В Донецьку святкують День зняття блокади 3 міста Ленінград», «Розгром німецькофашистських військ під Москвою, крах гітлерівського Бліцкрігу».

$15 \%$ - ефірного новинного часу зайняла підбірка репортажів по перемовинах щодо Донбасу. Серед них були такі: «Київ знову прагне перекласти свою відповідальність за блокування переговорного процесу», «Київ робить все можливе задля посилення стагнації в переговорному процесі», «Підведені підсумки засідання робочої групи по питаннях безпеки на переговорах в Мінську».

$11 \%$ - інформація про суспільне та культурне життя так званої «ДНР». Цьому наповненню відповідають такі новини: «В Донецьку відкрилась виставка робіт польського фотографа», «Наше минуле та майбутнє пов'язане з Росією - заявив Денис Пушилін», «В Республіці відбулось відкрите обговорення доктрини «Російський Донбас» 3 представниками 3МІ». Як бачимо, значна кількість суспільного i культурного життя в «республіці» крутиться навколо політичної орієнтації на Росію.

9\% - Політика дискримінації Києва. Як от: «В гонитві за політичними перевагами Київ цинічно маніпулює долями людей», «Розв’язана Києвом політика дискримінації за національною та мовною ознакою протирічить цілому ряду актів міжнародного права».

$4 \%$ - блок «Здобутки збройних сил ДНР»: «Денис Пушилін привітав військовослужбовців 1-го Гвардійського батальйону спецпризначення 3 річницею заснування підрозділу».

Таким чином, при проведенні аналізу контенту сайту «Міністерства інформації ДНР» було виокремлено такі основні тематики, що педалюються:

1. ЗСУ - загарбники, агресори та фашисти.

2. Велика Вітчизняна війна - подвиг радянських військ.

3. «Київська» влада гальмує перемовини.

4. «Київська» влада дискримінує за мовною ознакою.

Тобто, 3 урахуванням кількісного та якісного наповнення реалізованих проектів міністерства («Білі журавлі», «Трибунал»), можна стверджувати про 
формування таких ціннісних суспільних орієнтацій у так званій «ДНР»: агресія по відношенню до України; не сприйняття усього українського (на це працює ярлик «Київська» влада, а не українська); спільна російсько-донецька історія (звучить доволі дивно), сучасність та, відповідно, майбутнє; з Україною - не по дорозі, адже «Київська» влада дискримінує за мовною ознакою.

Схоже дослідження було проведене iз новинною стрічною «Міністерства зв'язку та масових комунікацій Луганської народної республіки».

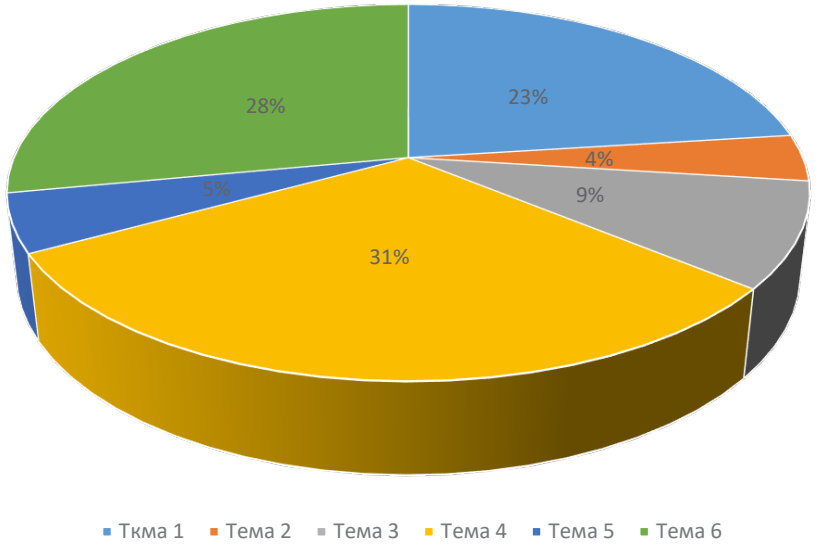

Діаграма 2. Новинна тематика сайту "Tribunal" за січень 2021 р.

Тематика січневих новин 2021 р. «Міністерства» («Міністерство») також була розподілена на шість основних блоків (діаграма 2 ), підрахована кількість новин у кожному блоці за досліджуваний період та, таким чином, встановлена пріоритетність тематики контенту (Мир Луганщині. Новини).

$31 \%$ усіх новин січня 2021 р. становлять новини в умовній рубриці «Діяльність активістів та волонтерів у соціальній сфері». Тут зустрічаються такі новини як «Активісток міста Земігор'є привітали 3 днем Татьяни», «Краснолучські активісти привели в порядок місця покинутих поховань», «Активісти провели в порядок територію Алеї Слави в Перевальську».

28\% - Молодіжна політика і культура: «Зустріч із студентами на тему: «Роль молоді в суспільно-політичному житті ЛНР» відбулась в Ровеньках», «В Луганську відсвяткували День студента», «Денис Мірошниченко привітав молодь 3 днем студента».

$23 \%$ - висвітлення діяльності проектів «Волонтер», «Мир Луганщині», «Рука допомоги»: «Стахановські активісти ОД «Мир Луганщині» в день студента отримали подяку та подарунки», «Відбулась зустріч активістів алчевської територіальної організації ОД «Мир
Луганщині»», «Волонтери організації «Рука допомоги» допомогли 37 жителям республіки».

9\% - Турбота про ветеранів: «В громадській організації «Мир Луганщині виражають співчуття у зв'язку зі смертю ветерана Алєксєя Воронова», «Депутати та активісти ОД «Мир Луганщині» привітали блокадників з 77-ою річницею повного визволення Ленінграда», «В Кіровську відвідали жителів блокадного Ленінграду»

$5 \%$ - умовний блок «Діди воювали» «В Луганську стартували змагання 3 кульової стрільби «Ворошиловський стрілок»», «Перевальські активісти провели суботник біля Братської могили радянських воїнів», «Година пам'яті», «Будемо пам'ятати подвиг Ленінграда відбулась у Земигор'ї».

4\% - блок «Боротьба за «русскій мир» у ЛНР»: «В Луганську для студентів провели брейн-ринг «Луганськ російське місто»», «Ми відстояли свою позицію, боролись та продовжуємо боротись за Русскій мир на нашій землі, - заявив Л. Пасєчнік» «Л. Пасєчнік про доктрину «Русскій Донбас»: Це достойна відповідь на багаторічні спроби знищення російської мови і культури, історії».

Таким чином, при проведенні аналізу 
контенту сайту «Міністерства зв’язку та масових комунікацій Луганської народної республіки» було виокремлено такі основні тематики, що педалюються:

1. Діяльність активістів та волонтерів, що працюють на розвиток республіки.

2. Основа подальшого успішного розвитку - робота з молоддю.

3. Турбота про ветеранів та підтримка пам'яті про події Великої вітчизняної війни (привіт від російського трактування історії Другої світової війни).

4. Русскій мир на Донбасі - наше майбутнє.

Таким чином, інформаційне міністерство «ЛНР» працює на підтримку парадигми єдиного майбутнього з Росією, а рушійною силою цього процесу повинна стати активна молодь та волонтери.

\section{Висновки}

Словосполучення реінтеграція» віднедавна з'явилось в українському інформаційному просторі. На практиці ж повернення тимчасово окупованих території супроводжуватиметься ще великою кількістю законів та правових норм, які покликані будуть легітимізувати цей процес. Проте чи не найбільшою проблемою, на думку автора, є свідомість місцевого населення, яку «прокачували» у певному напрямку i яку «годували» інформацією в рамках певних наративів.

Для аналізу інформаційного контенту у дослідженні було взято сайти «інформаційних» міністерств так званих «ЛДНР» - «Міністерства інформації Донецької національної республіки» - «Міністерства інформації ДНР» та «Міністерства зв'язку та масових комунікацій Луганської народної республіки». Було проведено огляд новин на сайтах міністерств за січень 2021 р. Усі новини були згруповані за тематикою у шість основних блоків, встановлено відсоткову вагу кожного блоку та візуалізовано в роботі за допомогою графічного методу. Це дозволило побачити основні напрямки діяльності міністерств та новинну проблематику. Так, інформаційна діяльність «Міністерства інформації ДНР» $\epsilon$ загалом більш агресивна та нетерпима по відношенню до України та усього українського: ЗСУ тут замінили на Військові формування України (перегукується 3 радянським кліше «бандформування»), «українська влада» замінили на «київська влада» (повинно сприйматись як влада, що не легітимна на території всієї країни, а як та, що керує внаслідок перевороту та поширюється лише на Київ). Окрім цього, присутність на сайті таких проектів як «Трибунал» та «Білі журавлі», що героїзують місцевих «воїнів» бойовиків та розповідають про злочини «ВФУ» вказує на інформаційне поле, що функціонує в рамках таких наративів: агресія по відношенню до України; не сприйняття усього українського; спільна російсько-донецька історія, сучасність та, відповідно, майбутнє; 3 Україною - не по дорозі, адже «Київська» влада дискримінує за мовною ознакою.

Новинна стрічка «Міністерства зв'язку та масових комунікацій Луганської народної республіки» в своїй риториці менш агресивна по відношенню до України, проте містить більше пропагандистського матеріалу щодо чіткої політичної, економічної та історичної орієнтації на Російську Федерацію. Таким чином, інформаційне міністерство так званих «ЛНР» працює на підтримку парадигми єдиного майбутнього з Росією, а рушійною силою цього процесу повинна стати активна молодь та волонтери.

Таким чином, сформульована на початку дослідження гіпотеза отримала своє підтвердження: наративи сучасної інформаційної політики, що формулює у суспільній свідомості квазівлада на окупованих територіях не тільки не сприяють безпечній реінтеграції, але й сприяють подальшому загостренню протистояння 3 Україною та зближенню 3 РФ.

3 огляду на проведені дослідження, основним завданням української влади, $\epsilon$ робота 3 мізками місцевого населення та вироблення нових, спільних наративів як для окупованих територій, так і для решти населення України. 


\section{БІБЛІОГРАФІЧНІ ПОСИЛАННЯ}

«Білі журавлі». URL: http://podvig-dnr.ru.

«Міністерство зв’язку та масових комунікацій Луганської народної республіки». URL: https://mslnr.su.

«Міністерство інформації ДНР». URL: https:/www.youtube.com/channel/UCTH3nTwj5EgsbXRA4QhOYDg. «Трибунал». URL: http://tribunal-dnr.ru.

Карпиленко В. А. Використання наративів у когнітивних структурах новин. Інформаџійне суспільство. 2014. Вип. 20. С. 9-11.

Карпиленко В.А. Функціонування наративів і особливості управління ними в системі соціальних комунікацій. «Young Scientist». 2015. № 2 (17) February. C. 549-552. URL: http://molodyvcheny.in.ua/files/journal/2015/2/423.pdf. Мир Луганщині. Новини. URL: https://mir-lug.info/novosti/page/9/.

Міністерств інформації ДНР. URL: https://mininfodnr.ru.

Ожеван М. Глобальна війна стратегічних наративів: виклики та ризики для України. Стратегічні пріоритети. 2014. № 4. URL: http://ippi.org.ua/sites/default/files/ozevan.pdf.

Почепцов Г. Г. Когнітивні підходи до аналізу інформаційного простору. Детектор медіа. 2012, 21 жовтня. URL: https://ms.detector.media/manipulyatsii/post/5895/2012-10-21-kognityvni-pidkhody-do-analizuinformatsiynogo-prostoru/.

Почепцов Г. Г. Контроль над розумом. Київ: Видавничий дім «Києво-Могилянська академія», 2012. 350 с

Стратегічні комунікації в міжнародних відносинах : монографія. Київ : Вадекс, 2019. 442 с. URL: http:// stratcom.nuou.org.ua/wp-content/uploads/2019/10/SCvmegdunar.pdf.

Сучасна політична лексика : енциклопед. словник-довідник / І. Я. Вдовичин, Л. Я. Угрин, Г. В. Шипунов та ін.; за наук. ред. Хоми Н. М. Львів : «Новий Світ-2000», 2015. 396 с.

\section{REFERENCES}

"Bili zhuravli”[White storks]. Retrieved from http://podvig-dnr.ru [in Russian].

Karpylenko, V. A. (2014). Vykorystannia naratyviv u kognitybnykh strukturakh novyn [Rhetoric use in cognitive news structures]. Information society, 20, 9-11 [in Ukrainian].

Karpylenko, V. A. (2015). Funktsionuvannia naratyviv i osoblyvosti upravlinnia nymy v systemi komunikatsiy [Rhetoric functioning and peculiarities of its manamegent in the system of social communications]. Young Scientist, 2 (17) February, 549-552. Retrieved from http://molodyvcheny.in.ua/files/journal/2015/2/423.pdf [in Ukrainian].

"Ministerstva zviazku ta masovykh komunikatsiy Luhanskoyi narodnoyi respubliky" [Ministry of communication and mass communication of Luhansk People's Republic]. Retrieved from https://mslnr.su [in Russian].

Ministerstvo informatsiyi DNR [Ministry of Information of Donetsk People's Republic]. Retrieved from https:// mininfodnr.ru [in Russian].

"Ministerstvo informatsiyi DNR" [Ministry of Information of Donetsk People's Republic]. Retrieved from https:// www.youtube.com/channel/UCTH3nTwj5EgsbXRA4QhOYDg [in Russian].

Myr Luhanshchyni. Novyny. [Peace to Luhansk Region. News] Retrieved from https://mir-lug.info/novosti/page/9/ [in Russian].

Ozhevan, M. (2014). Hlobalna viyna strategichnykh naratyviv: Vyklyky ta ryzyky dlia Ukrayiny [Global warfare with strategic rhetoric: challenges and risks for Ukraine]. Strategichni priorytety - Stratetic priorities, 4 . Retrieved from http://ippi.org.ua/sites/default/files/ozevan.pdf [in Ukrainian].

Pocheptsov, H. H. (2012a, October 21). Kognityvni pidkhody do analizu informatsiynoho prostoru [Cognitive approaches to the analysis of informational space]. Detector media. Retrieved from https://ms.detector.media/ manipulyatsii/post/5895/2012-10-21-kognityvni-pidkhody-do-analizu-informatsiynogo-prostoru/ [in Ukrainian].

Pocheptsov, H. H. (2012b). Kontrol nad rozumom [Control over mind]. Kyiv: Publishing house "Kyiv-Mohyla Academy" [in Russian].

Strategichni comunikatsiy v mizhnarodnykh vidnosynakh [Strategic communication in international relations]. (2019). Kyiv: Vadeks. Retrieved from http://stratcom.nuou.org.ua/wp-content/uploads/2019/10/SCvmegdunar.pdf.

"Trybunal" [Tribunal]. Retrieved from http://tribunal-dnr.ru [in Russian].

Vdovychyn, I. Ya., Uhryn, L. Ya., Shypunov, H. V. et al. (2015). Suchasna politychna leksyka: Encykloped. Slovnykdovidnyk [Modern political vocabulary: encyclopedic glossary]. Khoma N. M. (Ed.). Lviv: "Novyi Svit-2000" [in Ukrainian].

Malyk Iryna

Ph.D., Assoc. Prof., https://orcid.org/0000-0002-5638-6999, Lisotska.i.r@gmail.com

Стаття надійшла / Article arrived: 01.01.2021

Схвалено до друку / Accepted: 20.01.2021 